\title{
A new case of congenital dyserythropoietic anaemia, type III: studies of the cell cycle distribution and ultrastructure of erythroblasts and of nucleic acid synthesis in marrow cells
}

\author{
SN WICKRAMASINGHE, TE PARRY, C WILLIAMS, AN BOND, MADELEINE \\ HUGHES, SALLY CROOK
}

From the Department of Haematology, St Mary's Hospital Medical School, London W2 1PG and the Department of Haematology, Llandough Hospital, Penarth, Glamorgan, Wales

SUMMARY The clinical and laboratory findings in an asymptomatic 19-year-old Welshman with congenital dyserythropoietic anaemia (CDA) type III are described. The blood film showed macrocytosis and red cell fragmentation and there was biochemical evidence of intravascular haemolysis. The bone marrow showed erythroid hyperplasia, megaloblastic erythropoiesis and several giant multinucleate erythroblasts. Some mononucleate erythroblasts were large and had relative DNA contents of $4-8 \mathrm{c}$ and the bi- and multinucleate erythroblasts had total DNA contents of 2-16c. Some of the multinucleate erythroblasts displayed a variety of ultrastructural abnormalities, including marked differences in the appearances of the individual nuclei within the same cell. The marrow cells gave a normal deoxyuridine-suppressed value indicating that the megaloblastic changes were not caused by an impairment of the methylation of deoxyuridylate. The rates of incorporation of ${ }^{14} \mathrm{C}$-glycine and ${ }^{14} \mathrm{C}$-adenine into both the DNA and RNA of bone marrow cells were within the normal range. Furthermore, the average rate of elongation of newly-synthesised, ${ }^{3} \mathrm{H}$-thymidine-labelled daughter DNA strands, assessed by hydroxyapatite chromatography of alkali-denatured DNA was found to be normal. The results suggest that there is no impairment of DNA replication in the majority of the erythroblasts and that the abnormality of erythropoiesis resulted from disturbances during mitosis and the $\mathrm{G}_{2}$ phase.

Congenital dyserythropoietic anaemia (CDA) type III is very rare and has only been reported in a few families. ${ }^{1-4}$ This disorder is characterised by a macrocytic anaemia, normal granulocyte and platelet counts, megaloblastic erythropoiesis in the absence of vitamin $B_{12}$ or folate deficiency and the presence in the marrow of some large uninucleate erythroblasts with big, lobulated nuclei and of many giant multinucleate erythroblasts. The disease runs a protracted and relatively benign clinical course. In the present paper we describe the clinical and haematological features of a new case of CDA type III-the first to be reported from the British Isles. In addition, we present the results of studies into (i) the ultrastructure and proliferative characteristics of the erythroblasts and (ii) some aspects of the biochemistry of DNA synthesis in the bone marrow

Accepted for publication 24 February 1982 cells of this case. The investigations of DNA synthesis were undertaken in an attempt to understand the biochemical basis underlying the megaloblastic change in this disease and have not been performed by previous workers.

\section{Material and methods}

\section{CASE REPORT}

A 19-year-old carpenter's apprentice (case GD) was rejected as a blood donor in June 1980 because his haemoglobin was too low. He had donated blood on one occasion nine months previously. He felt perfectly fit, only took alcoholic drinks occasionally and was not on any drugs. There was, however, a history of anaemia and jaundice during the first year of life and he had attended a paediatric clinic regularly up to the age of five. Unfortunately, his outpatient records could not be traced. There was 
no family history of anaemia. The only abnormal findings on clinical examination were very mild cutaneous icterus, and a firm, enlarged spleen which was palpable about $8 \mathrm{~cm}$ below the left costal margin. The liver edge was also palpable and firm.

The results of a blood count were: $\mathrm{Hb} 11.9 \mathrm{~g} / \mathrm{dl}$, RBC $3.23 \times 10^{12} / 1$, PCV 0.343, MCV $104 \mathrm{fl}, \mathrm{MCH}$ $36.6 \mathrm{pg}$, MCHC $35.0 \mathrm{~g} / \mathrm{dl}$, reticulocytes $0.07 \times$ $10^{12} / \mathrm{l}$, WBC $7.7 \times 10^{9} / 1$, platelets $230 \times 10^{9} / 1$. The blood film showed macrocytosis together with a moderate degree of red cell fragmentation (Fig. la). The results of some of the other investigations were: blood group $\mathrm{B} \mathrm{Rh}$ positive; direct and indirect Coombs' tests, negative; serum vitamin $B_{12} 240 \mathrm{ng} / \mathrm{l}$; serum folate $7 \cdot 3 \mu \mathrm{g} / \mathrm{l}$; serum ferritin $145 \mu \mathrm{g} / \mathrm{l}$ (normal 39-340); HbF 0.33\% (normal 0.1-0.8); $\mathrm{HbA}_{2} 2 \cdot 88 \%$ (normal $1 \cdot 5-3 \cdot 5$ ); test for unstable $\mathrm{Hb}$ using the isopropanol method, negative; $\mathrm{Hb}$ electrophoresis on cellulose acetate $(\mathrm{pH} 8.6)$ and citrate agar (pH 6.0), normal; autohaemolysis (24 h) and osmotic fragility ( 0 and $24 \mathrm{~h}$ ), normal; serum bilirubin $40 \mu \mathrm{mol} / \mathrm{l}$ (normal 5-17), conjugated

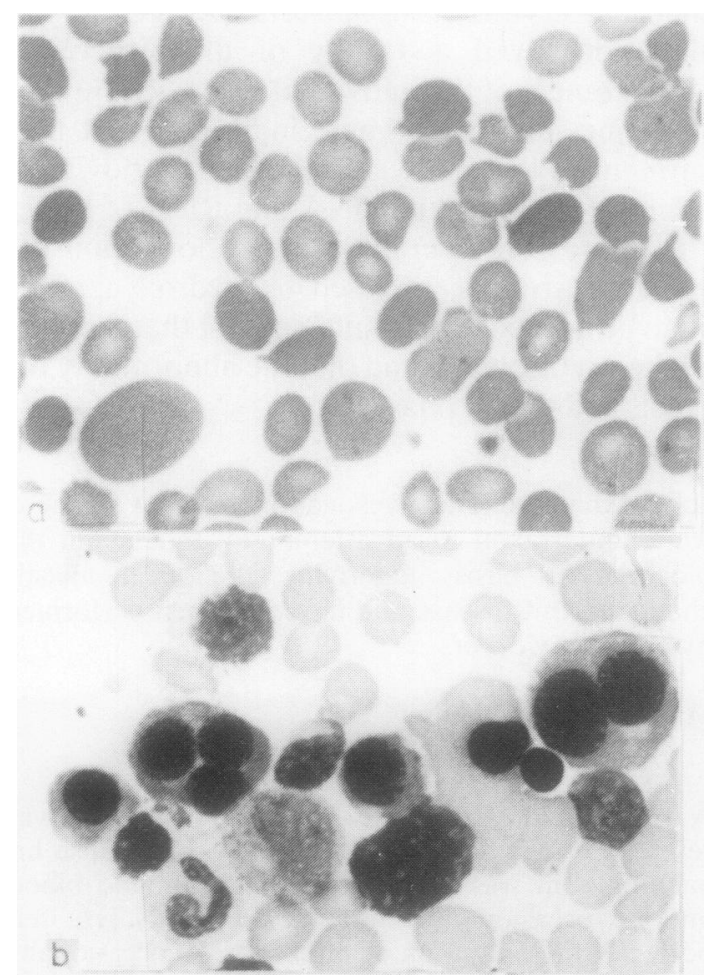

Fig. 1 May-Grünwald-Giemsa-stained peripheral blood film ( $a$ ) and bone marrow smear (b) of case GD. The blood film shows marked anisocytosis, macrocytes and poikilocytes. The marrow smear contains multinucleate erythroblasts. bilirubin $7.2 \mu \mathrm{mol} / \mathrm{l}$; plasma oxyhaemoglobin $0.008 \mathrm{~g} / \mathrm{dl}$ (normal 0.001-0.004); Schumm's test, weakly-positive; haptoglobin $0.135 \mathrm{~g} / \mathrm{dl}$ (normal $0 \cdot 5-2 \cdot 5$ ). The sucrose lysis test was negative and the Ham's acidified serum haemolysis test was likewise repeatedly negative against fresh normal $\mathrm{ABO}$ compatible serum. Examination of the urine revealed the absence of bilirubin, a slight increase of urobilinogen and a persistent haemosiderinuria.

A sternal marrow aspirate showed erythroid hyperplasia and several of the erythroblasts showed definite megaloblastic changes. However, the megaloblastic changes were not as florid as in severe pernicious anaemia. The myeloid:erythroid ratio was

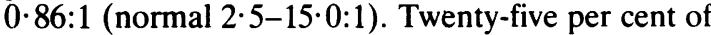
the erythroblasts contained two nuclei per cell, $6 \%$ contained 3 and $4 \%$ contained 4 nuclei per cell (Fig. 1b). An occasional erythroblast contained 5-9 nuclear masses. There were also some giant mononucleate erythroblasts. Most of the bi- and multinucleate cells consisted of early or late polychromatic erythroblasts but a few consisted of basophilic erythropoietic cells. Sometimes the two nuclei within a binucleate cell or two or more of the nuclei within a multinucleate cell were joined together by a narrow strand of chromatin or appeared to be stuck togethero over a wide area of contact. The two or more nuclear masses present within multinucleate erythroblastso were rounded in outline and equal in size and staining characteristics in some cells, but were irregular in shape, unequal in size or, very occasionally, different in their staining characteristics in others. Other abnormalities affecting some erythroblasts included coarse basophilic stippling of the cytoplasm. the presence of multipolar mitotic spindles and karyorrhexis of interphase nuclei. Several giant erythrocytes were present. Granulocyte precursors and megakaryocytes displayed normal morphology. There was no stainable iron in the marrow fragments.

The mother and sister of case GD were haematologically normal, but his father attended a sarcoid clinic and was known to have an enlarged spleen. The father has not been investigated haematologically.

SPECIAL STUDIES OF MARROW CELLS

The patient was treated with $5 \mathrm{mg}$ folic acid bd for 1 week prior to the studies on the bone marrow cells.

\section{Cell cycle distribution of marrow cells}

This was determined using the method of combined Feulgen microspectrophotometry and ${ }^{3} \mathrm{H}$-thymidine autoradiography as described previously. ${ }^{5}$

\section{Ultrastructural studies}

Marrow fragments were fixed in $2.5 \%$ glutaraldehyde in $0 \cdot 1 M$ phosphate buffer $(\mathrm{pH} 7 \cdot 3)$ at $4^{\circ} \mathrm{C}$ 
for $12 \mathrm{~h}$ and processed for electron microscopy as detailed earlier. ${ }^{6}$

\section{Deoxyuridine suppression test}

The technique reported by Wickramasinghe and Saunders ${ }^{7}$ was used to determine the deoxyuridinesuppressed value given by the bone marrow cells.

\section{Incorporation of ${ }^{14} \mathrm{C}$-glycine and ${ }^{14} \mathrm{C}$-adenine}

The incorporation of these radioactive compounds into the DNA and RNA of bone marrow cells was determined using a method based on that described by Feinendegen $e t a^{8}$ as reported previously. ${ }^{9}$

\section{Rate of DNA chain elongation}

Marrow cells were pulse-labelled with [methyl- ${ }^{3} \mathrm{H}$ ] thymidine $(150 \mu \mathrm{Ci} / \mathrm{ml}$, about $7 \mu M)$ for $30 \mathrm{~s}$ and some were chased for $1 \mathrm{~h}$ in $10 \mu M$ non-radioactive nucleoside. The DNA of the ${ }^{3} \mathrm{H}$-thymidine-labelled cells was subjected to alkali denaturation using $\mathrm{NaOH}$ at concentrations in the range $0-0.04 M$. Single-stranded (ss) DNA was then separated from double-stranded DNA by chromatography on hydroxyapatite (HTP) as described elsewhere. ${ }^{10}$
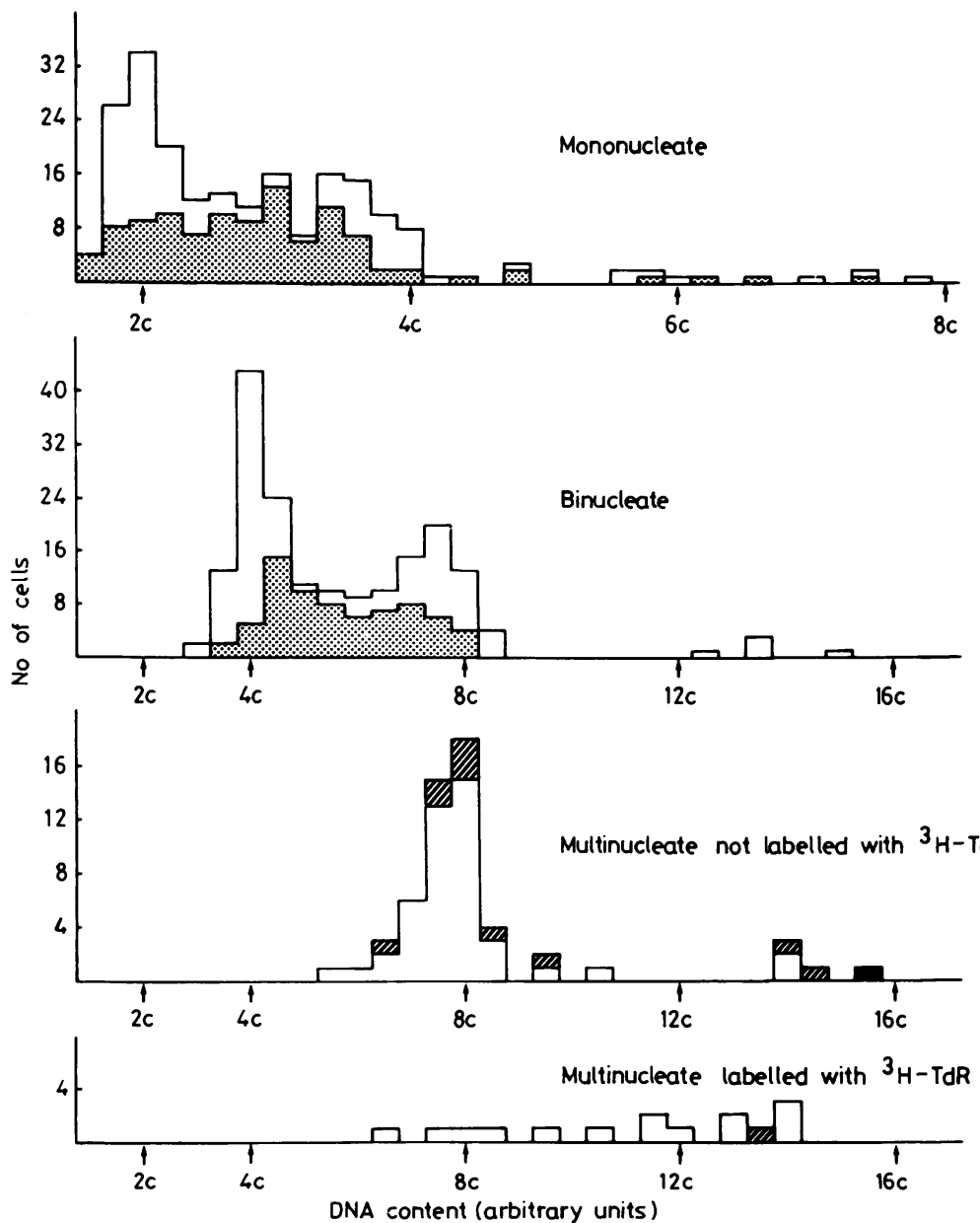

Fig. 2 Distributions of the total DNA contents of the mononucleate, binucleate and multinucleate polychromatic and orthochromatic erythroblasts. In the histograms relating to the mono-and bi-nucleate cells, the stippled areas represent cells which incorporated ${ }^{3} \mathrm{H}$-thymidine $\left({ }^{3} \mathrm{H}\right.$-TdR). 3.6\% of the "diploid" mononucleate cells were unlabelled with ${ }^{3} H$-TdR despite DNA contents in between the $G_{1}$ and $G_{2}$ values. The ratio of the number of these mononucleate cells in $S$ to the number in $G_{2}$ was $3 \cdot 3$. In the histograms relating to the multinucleate cells, the open, cross-hatched and solid areas represent erythroblasts with 3, 4, and 6 nuclei, respectively. 

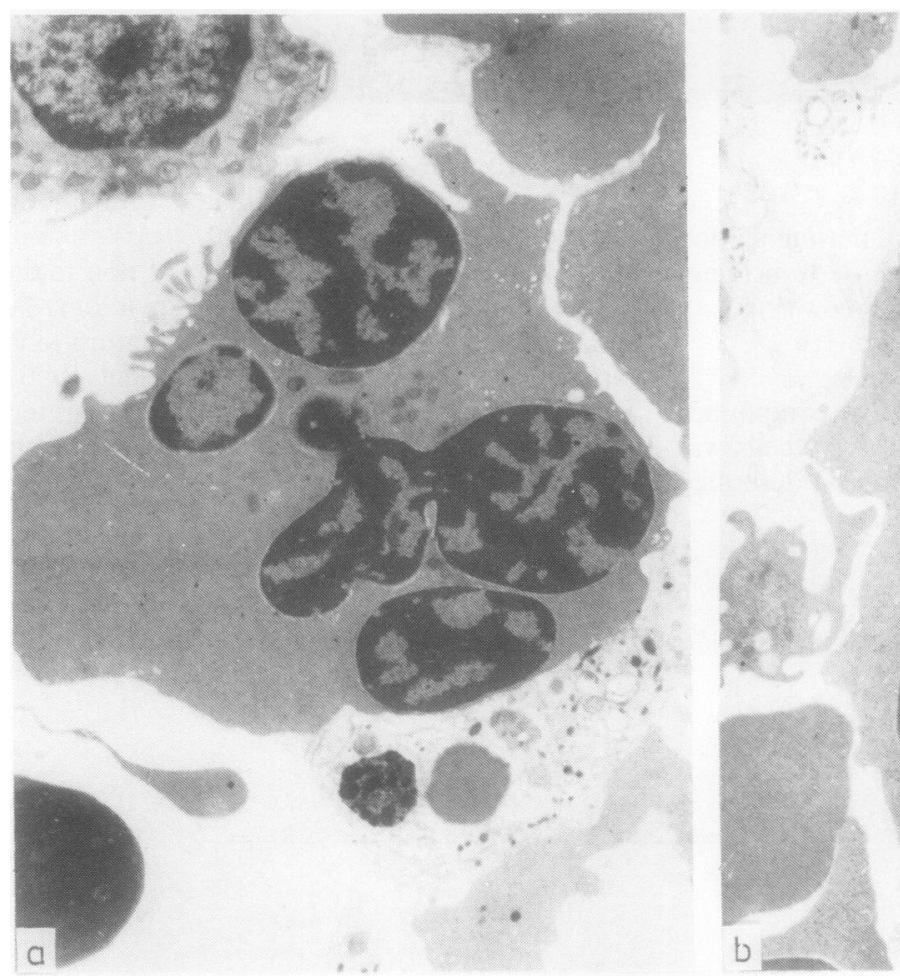

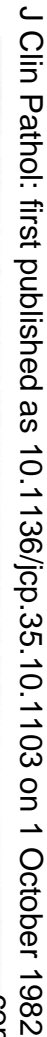
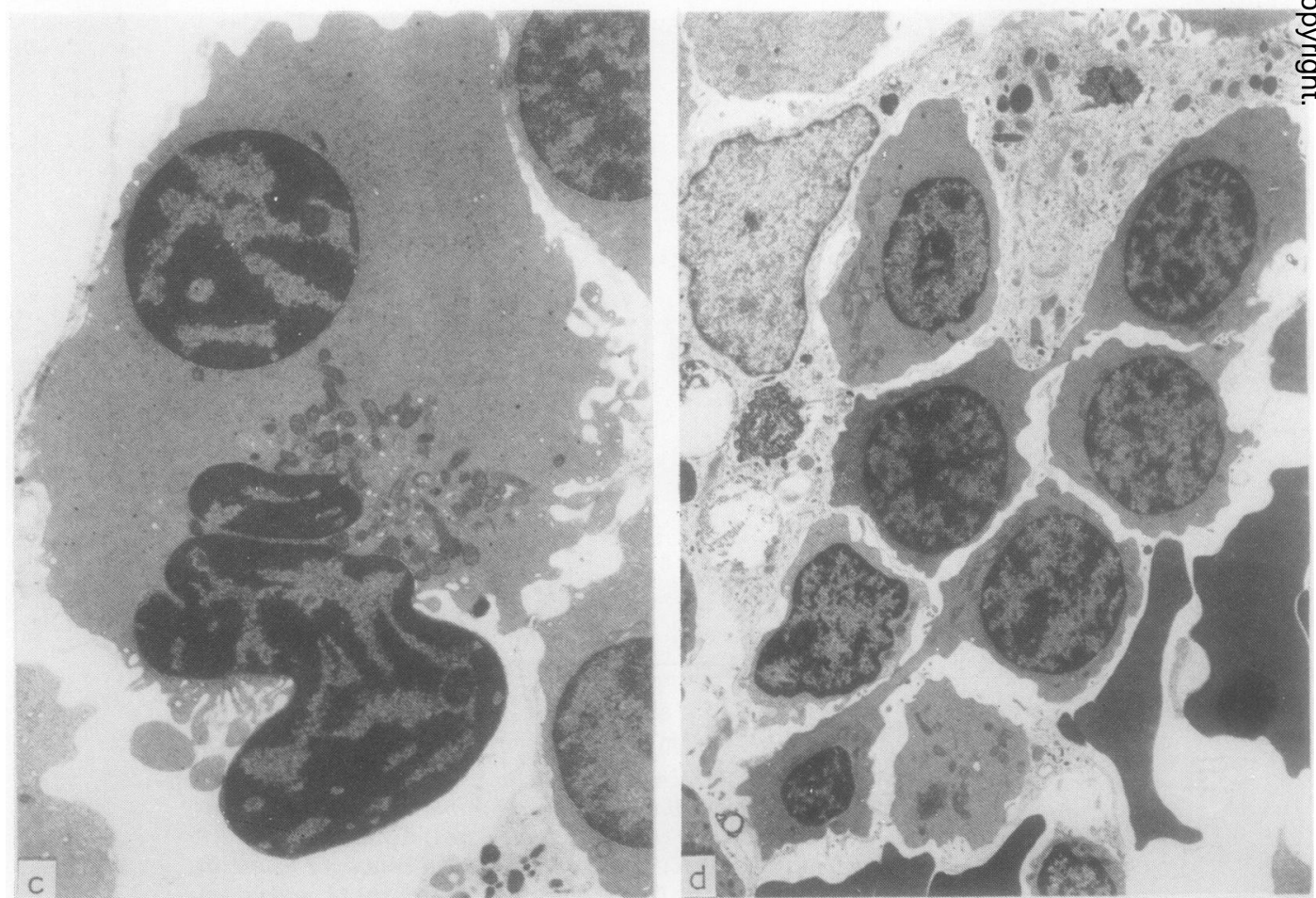

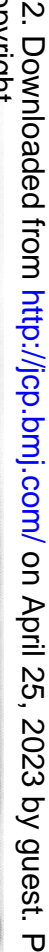

Fig. 3 Electron micrographs of erythroblasts from case $G D$. (a) lobulation of the nucleus $\times 6150 ;(b)$ one normal-oำ looking nucleus and one nucleus displaying the Swiss-cheese appearance in the same cell $\times 6900 ;$; (c) partial expulsion of $\stackrel{\mathbb{D}}{\circ}$ the larger of the two nuclei of a binucleate cell $\times 6300 ;(d)$ two inter-erythroblastic spindle bridges $\times 3100$. 


\section{Results}

\section{CELL CYCLE STUDIES}

Of the mononucleate basophilic erythropoietic cells, $34 \%$ were in $G_{1}, 58 \%$ were in $S$ and $8 \%$ were in $G_{2}$. Figure 2 gives the frequency distribution of the Feulgen absorbance values (relative DNA contents) of the mononucleate and multinucleate polychromatic and orthochromatic erythroblasts. It is evident that some of the mononucleate cells with DNA contents between the $G_{1}$ and $G_{2}$ values were unlabelled with ${ }^{3} \mathrm{H}$-thymidine. It can also be seen that a few of the mononucleate polychromatic or orthochromatic erythroblasts had hypertetraploid DNA contents and that the multinucleate cells had total DNA contents between 2 and 16c. When the individual nuclear masses within a multinucleate cell varied considerably in size, their DNA contents varied by a factor of 2-6 between the smallest and largest mass. The ${ }^{3} \mathrm{H}$-thymidine labelling indices of erythroblasts with 2, 3 and 4 or more nuclear masses were 40,24 and $9 \%$ respectively. Although the majority of the DNA-synthesising bi- and multinucleate erythroblasts were labelled in both or all nuclei, a few contained one or two unlabelled nuclei.

Of cells belonging to the promyelocyte-myelocyte pool $77 \%$ were in $\mathrm{G}_{1}, 22 \%$ in $\mathrm{S}$ (normal 20-34) and $1 \%$ in $\mathrm{G}_{2}$.

\section{ULTRASTRUCTURAL STUDIES}

Many multinucleate erythroblasts were examined and a variety of ultrastructural abnormalities were detected in some of these cell profiles. The most frequent abnormality was the presence of intranuclear clefts. Some multinucleate cells contained two or more nuclear masses which appeared to have adhered together and others had nuclei which were markedly lobulated (Fig. 3a) or were undergoing karyorrhexis. The adherent nuclei showed a variable extent of loss of the nuclear membrane at the area of adherence. Occasionally, one or more of the nuclei within the same multinucleate cell were ultrastructurally different from the others (Fig. 3b). Other dyserythropoietic features shown by a few erythroblast nuclei included duplication, loss or myelinisation of parts of the nuclear membrane. Some bi- and multinucleate cells appeared to be in the process of expelling one of their nuclei but not the others (Fig. 3c). The cytoplasm of multinucleate erythroblasts sometimes contained siderosomes, autophagic vacuoles, or an excess of microtubules and very occasionally contained moderately ironladen mitochondria. Some of the autophagic vacuoles contained myelin figures. A few of the erythroblast profiles were joined together by intercellular spindle bridges (Fig. 3d).

Some bone marrow macrophages contained phagocytosed erythroblasts at various stages of degradation.

DEOXYURIDINE SUPPRESSION TEST

The bone marrow cells gave a deoxyuridinesuppressed value of $2.0 \%$ (normal range 1.4$8 \cdot 6 \%)$.

\section{INCORPORATION OF ${ }^{14} \mathrm{C}-\mathrm{GLYCINE}$ AND ${ }^{14} \mathrm{C}-\mathrm{A}$ DENINE}

The incorporation of these substances into DNA and RNA are given in the Table and were within the normal ranges reported by Wickramasinghe and Saunders. ${ }^{9}$

\section{RATE OF DNA CHAIN ELONGATION}

Figure 4 shows the HTP chromatography elution patterns of our patient's marrow cells after pulselabelling with ${ }^{3} \mathrm{H}$-thymidine for $30 \mathrm{~s}$ and after chasing the radioactivity for $1 \mathrm{~h}$. At any particular alkali molarity, the decrease in the percentage of ssDNA between these two times gives a measure of the rate of DNA daughter-strand elongation. It can be seen that

Incorporation of ${ }^{14} \mathrm{C}$-glycine and ${ }^{14} \mathrm{C}$-adenine into the DNA and RNA of the bone marrow cells of case $G D$

\begin{tabular}{|c|c|c|c|}
\hline \multirow[t]{2}{*}{ Radioactive precursor } & \multirow[t]{2}{*}{ Units of incorporation } & \multicolumn{2}{|c|}{ Incorporation into $D N A$ and $R N A$} \\
\hline & & Case GD* & Normal ranget \\
\hline${ }^{14} \mathrm{C}$-glycine & $\begin{array}{l}\text { cpm in DNA } / 10^{6} \text { cells } \\
\text { cpm in DNA } / 10^{6} \mathrm{~S} \text {-cells } \\
\text { cpm } / \mu \mathrm{g} \text { DNA } \\
\text { cpm in RNA } / 10^{6} \text { cells } \\
\text { cpm/RNA absorbance unit }\end{array}$ & $\begin{array}{r}156 \\
456 \\
28 \\
86 \\
142\end{array}$ & $\begin{array}{c}61-294 \\
289-1537 \\
10-192 \\
37-218 \\
141-1016\end{array}$ \\
\hline${ }^{14} \mathrm{C}$-adenine & $\begin{array}{l}\text { cpm in DNA } / 10^{6} \text { cells } \\
\text { cpm in DNA } / 10^{6} \mathrm{~S} \text {-cells } \\
\text { cpm } / \mu \mathrm{g} \text { DNA } \\
\text { cpm in RNA } / 10^{6} \text { cells } \\
\text { cpm/RNA absorbance unit }\end{array}$ & $\begin{array}{r}163 \\
476 \\
30 \\
840 \\
2294\end{array}$ & $\begin{array}{c}39-205 \\
171-1501 \\
14-101 \\
515-2500 \\
1955-10317\end{array}$ \\
\hline
\end{tabular}

${ }^{* 3} \mathrm{H}$-TdR labelling index of nucleated marrow cells $=34 \cdot 3 \%$.

†From Wickramasinghe and Saunders.' 


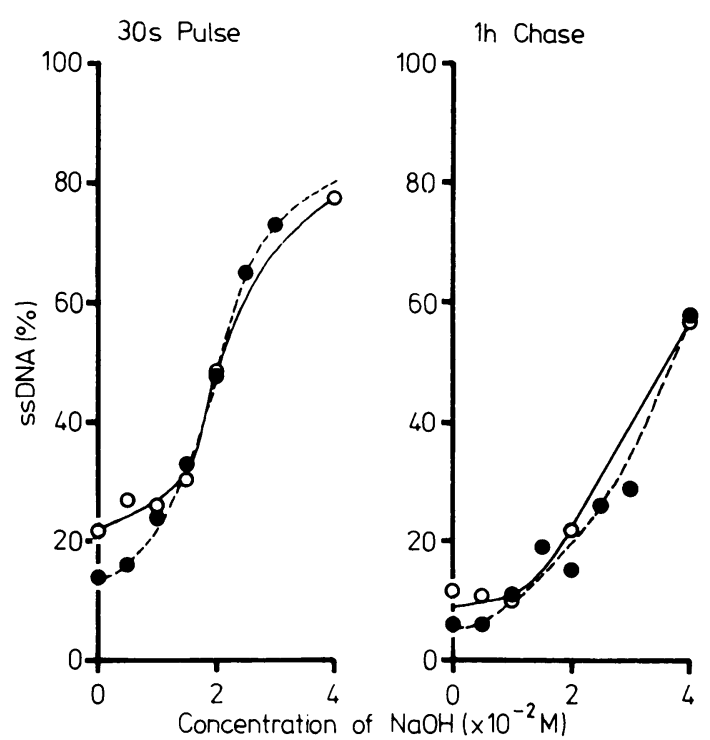

Fig. 4 Hydroxyapatite chromatography elution profiles showing the percentage of the DNA which was singlestranded after treatment with various concentrations of alkali. Bone marrow cells were pulse-labelled with $150 \mu \mathrm{Ci}$ $\mathrm{ml}^{3} \mathrm{H}$-thymidine for 30 s and some were chased for $60 \mathrm{~min}$ in $10 \mu M$ non-radioactive thymidine, prior to the

chromatographic analysis. $\bigcirc=$ control marrow cells (mean of 16 samples for the thirty-second pulse and of 12 samples for the one-hour chase); $\bullet=$ marrow cells from case $G D$.

the elution profiles after the 30 -second pulse and the one-hour chase are very similar to the corresponding elution profiles which were obtained by Bond $e t$ al $^{10}$ for the marrow cells of a heterogeneous group of patients with normoblastic erythropoiesis and no evidence of vitamin $B_{12}$ or folate deficiency. The diagnoses in this group included idiopathic thrombocytopenic purpura, malignant disease not involving the bone marrow, treated pernicious anaemia, iron deficiency anaemia, the anaemia of chronic disorder and chronic alcoholism.

\section{Discussion}

The haematological features of our patient are similar to those of patients classified by Heimpel and Wendt ${ }^{11}$ as congenital dyserythropoietic anaemia (CDA) type III.$^{1-4}$ However, a substantial degree of intravascular haemolysis has not been described in previously reported cases although these have shown an absence of haptoglobins. In the present case, the haemolysis was associated with a reduced haptoglobin concentration, methaemalbuminaemia and a slight to moderate degree of haemosiderinuria and appeared to result from the fragmentation of the macrocytic red cells. Splenomegaly was found in our case as well as in the case reported by Goudsmit et al $^{3}$ but was absent in those described by Wolff and von Hofe $^{1}$ and Bergström and Jacobsson. ${ }^{2}$ A difference between the present case and that described by Goudsmit $e t \mathrm{al}^{3}$ is that bi- and multinucleate basophilic erythropoietic cells were much more frequent in the latter than in the former. The primary biochemical defect in patients with CDA type III is unknown and there is no information as to whether the differences observed between different patients with this type of CDA indicate differences in the nature of the primary defect or not.

In the patient reported here, $3.6 \%$ (normal 0 $0.9)$ of the mononucleate polychromatic or orthochromatic erythroblasts with DNA contents including and below the $G_{2}$ value appeared to have become arrested after progressing through part of the $S$ phase. Furthermore, there was an excess of these cells in $G_{2}$ when compared with the number in $S$, so that the $S: G_{2}$ ratio was $3 \cdot 3$ (normal 6.8-13.7). The latter suggests an impairment in the progress of cells through $\mathrm{G}_{2}$ and indeed some $\mathrm{G}_{2}$ cells were seen to be undergoing karyorrhexis. The multinucleate erythroblasts of the present case had DNA contents of 2-16c and some of the mononucleate cells had totalo DNA contents of 4-8c. These DNA values are similar to those found in the case reported by Clauvel et $\mathrm{al}^{4} \rightleftharpoons$ but are lower than those in the patient studied by Wickramasinghe and Goudsmit ${ }^{5}$ in which the corresponding values were $2-40 c$ and $4-20 c$, respectively. The detailed studies of the cell cycle distribution and ultrastructure of the erythroblasts of case GD suggested that the bi- and multinucleate erythroblasts and the morphological diversity within these cells resulted from various combinations of the following processes: (i) acytokinesis, (ii) multipolar mitosis, (iii) the acquisition of hypertetraploid DNA contents in some nuclei (by endoreduplication of DNA, endomitosis, or the fusion of two or more nuclei), (iv) the absence of DNA synthesis in one or more of the nuclei within a DNA-synthesising multinucleate cell, (v) the loss of one of the nuclei from a multinucleate cell and (vi) karyorrhexis.

A variety of ultrastructural abnormalities were found in the multinucleate erythroblasts of case GD and these were qualitatively similar to those described in two other cases of CDA type III..$^{512}$ Some of the erythroblasts of case GD were found within the cytoplasm of bone marrow macrophages, providing direct evidence of ineffective erythropoiesis. The ineffectiveness of erythropoiesis was reflected in a low absolute reticulocyte count despite the erythroid hyperplasia. Ferrokinetic and erythrokinetic studies have indicated a considerable degree 
of ineffective erythropoiesis in two previouslyreported cases of CDA type III. ${ }^{314}$

None of the previous publications on CDA type III have included biochemical investigations of nucleic acid synthesis in the bone marrow cells. In the present study, we investigated the capacity of the bone marrow cells of case GD to (i) methylate deoxyuridylate to thymidylate (as judged by the deoxyuridine suppression test), (ii) incorporate ${ }^{14} \mathrm{C}$ glycine and ${ }^{14} \mathrm{C}$-adenine into DNA and RNA and (iii) elongate newly-synthesised ${ }^{3} \mathrm{H}$-thymidine-labelled daughter DNA strands. The results of all of these investigations were normal suggesting that there may be no abnormality in nucleic acid synthesis in the majority of the bone marrow cells. Evidently, in the present case, neither the megaloblastic erythropoiesis nor the apparent arrest of some erythroblasts during their progress through the $S$ phase resulted from a primary defect in DNA synthesis. As the data from the cell cycle studies suggest that the multinucleate and giant mononucleate erythroblasts were generated as a consequence of abnormalities in $\mathrm{G}_{2}$ and mitosis, it is possible that the megaloblastic erythropoiesis was also a consequence of disturbances in these two phases of the cell cycle.

The clinical and haematological features of this patient were presented by Dr TE Parry at a meeting of the Paediatric Pathology Society at Nottingham in September 1980.

\section{References}

1 Wolff JA, von Hofe FH. Familial erythroid multinuclearity. Blood 1951;6:1274-83.

${ }^{2}$ Bergström I, Jacobsson L. Hereditary benign erythroreticulosis. Blood 1962;19:296-303.
${ }^{3}$ Goudsmit R, Beckers D, de Bruijne JI, et al. Congenital dyserythropoietic anaemia, type III. Br J Haematol 1972; 23:97-105.

4 Clauvel JP, Cosson A, Breton-Gorius J, et al. Dyserythropoièse congenitale. Nouv Rev Fr Hémat 1972;12:653-72.

5 Wickramasinghe SN, Goudsmit R. Some aspects of the biology of multinucleate and giant mononucleate erythroblasts in a patient with CDA type III. Br J Haematol 1979;41:485-95.

- Wickramasinghe SN, Hughes M. Ultrastructural studies of erythropoiesis in $\beta$-thalassaemia trait. Br J Haematol 1980; 46:401-7.

${ }^{7}$ Wickramasinghe SN, Saunders JE. A fault in the design of the deoxyuridine suppression test. Clin Lab Haematol 1979;1: 69-71.

${ }^{*}$ Feinendegen LE, Bond VP, Painter RB. Studies on the inter-relationship of RNA synthesis, DNA synthesis and precursor pool in human tissue culture cells studied with tritiated pyrimidine nucleosides. Exp Cell Res 1961;22: 381-405.

9 Wickramasinghe SN, Saunders JE. Incorporation of radioactive precursors into the nucleic acids of bone marrow cells from patients with vitamin $\mathrm{B}_{12}$ or folate deficiency. Acta Haematol 1980;63:196-203.

${ }^{10}$ Bond AN, Harris G, Wickramasinghe SN. DNA chain elongation rates in marrow cells from vitamin $B_{12}$-deficient patients and methotrexate-treated mice. Br J Haematol 1982;50:299-307.

"Heimpel H, Wendt F. Congenital dyserythropoietic anemia with karyorrhexis and multinuclearity of erythroblasts. Helv Med Acta 1968;34:103-15.

${ }^{12}$ Breton-Gorius J, Daniel MT, Clauvel JP, Dreyfus B. Anomalies ultrastructurales des érythroblastes et des érythrocytes dans six cas de dysérythropoièse congenitale. Nouv Rev Fr Hémat 1973; 13:23-50.

${ }^{13}$ Goudsmit R. Congenital dyserythropoietic anaemia, type III. In: Lewis SM, Verwilghen RL, eds. Dyserythropoiesis. London: Academic Press, 1977:83-92.

${ }^{14}$ Faille A, Najean Y, Dresch C. Cinétique de l'erythropoièse dans 14 cas "d'erythropoièse inefficace" avec anomalies morphologiques des érythroblastes et polynucléarité. Nouv Rev Fr Hémat 1972;12:631-52.

Requests for reprints to: Professor SN Wickramasinghe, Department of Haematology, St Mary's Hospital Medical School, London W2 1PG. 